\title{
Interpreting erosion rates from cosmogenic radionuclide concentrations measured in rapidly eroding terrain
}

\author{
Liam J. Reinhardt, '* T. B. Hoey, ${ }^{2}$ T. T. Barrows, ${ }^{3}$ T. J. Dempster, ${ }^{2}$ P. Bishop ${ }^{2}$ and L. K. Fifield ${ }^{3}$ \\ Center for Earthquake Research and Information, University of Memphis, 3876 Central Avenue, TN 38152-3050, USA (formerly at the \\ Department of Geographical and Earth Sciences, University of Glasgow, UK) \\ ${ }^{2}$ Department of Geographical and Earth Sciences, University of Glasgow, UK \\ 3 Department of Nuclear Physics, Australian National University, Canberra, Australia
}

\author{
* Correspondence to: L. J. \\ Reinhardt, Centre for Earthquake \\ Research and Information, \\ University of Memphis, \\ 3876 Central Avenue, \\ TN 38/52-3050, USA. \\ E-mail:wjrnhrdt@Memphis.edu
}

Received 9 March 2005;

Revised 24 April 2006;

Accepted 23 June 2006

\begin{abstract}
A combination of numerical analysis and ${ }^{10} \mathrm{Be}$ concentrations measured in sediment samples from the high-relief Torrente catchment, southern Spain, allows us to investigate the sampling requirements for determining erosion rates using cosmogenic nuclides in high-relief, landslide-dominated terrain. We use simple modelling to quantify the effect of particle spalling and/or landsliding on erosion rates determined using a cosmogenic in-situ produced isotope. Analytical results show that the cosmogenic nuclide concentration of a surface experiencing regular detachment of a grain or block may be considered to be in steady state, and 'in-situ' erosion rates estimated, when an appropriate number of spatially independent samples are amalgamated. We present equations that enable calculation of the number of bedrock samples that must be amalgamated for the estimation of mean erosion rates on an outcrop experiencing regular detachment of a grain or chip of thickness $L$ every $T$ years. Our findings confirm that mean catchment erosion rates may be reliably estimated from ${ }^{10} \mathrm{Be}$ concentrations in fluvial sediment in high-relief rapidly eroding terrain. These catchment-wide integrated erosion rates can be calculated where erosion is primarily accomplished through shallow ( $<3 \mathrm{~m})$ spalling processes; where deep-seated $(>3 \mathrm{~m})$ landslides are the dominant mode of erosion only minimum erosion rates can be determined. Lastly, we present erosion rate measurements from the Torrente catchment that reveal variation of two orders of magnitude (0.03-1.6 m ka-1) quantifying the high degree of spatial variation in erosion rates expected within rapidly uplifting catchments. Copyright (C) 2006 John Wiley \& Sons, Ltd.
\end{abstract}

Keywords: cosmogenic nuclides; erosion; steady-state landscape; high relief; mountain; landsliding

\section{Introduction}

Erosion of high-relief, tectonically active mountain belts is highly localized and dominated by mass movement processes that vary both spatially and temporally (Hovius et al., 1998; Pratt-Sitaula et al., 2002; Dadson et al., 2003, 2004). Global topography indicates that high rates of surface uplift and river incision in tectonically active mountain belts typically generate $1000-2000 \mathrm{~m}$ of relief, whereas the generally declining relief of tectonically inactive mountain belts is typically $<1000 \mathrm{~m}$ (Montgomery and Brandon, 2002). Therefore, there are considered to be two fundamentally different types of landscapes with distinct geomorphological controls on landscape-scale erosion rates. In low-relief, low-gradient, post-orogenic mountain belts, hillslope processes set the pace of landscape lowering. In such environments, the rate of non-glacial erosive processes increases with hillslope gradient (Gilbert, 1909; Montgomery and Dietrich, 1994; Burbank, 2002). In contrast, mean catchment-scale erosion rates increase non-linearly with relief in high-relief tectonically active mountain belts (Montgomery and Brandon, 2002), because hillslopes adjust to high rates of tectonically driven rock uplift through changes in the frequency of shallow bedrock/regolith landslides rather than changing gradient (Burbank et al., 1996). A lack of techniques capable of measuring denudation over millennial 
timescales in such high-relief terrain means that the spatial and temporal patterns of erosion have hitherto remained largely unquantified.

Quantification of spatial and temporal patterns of erosion in high-relief terrain has been made potentially more tractable by the development of techniques employing terrestrial cosmogenic nuclides in both in-situ bedrock and sediment samples (Lal, 1991; Brown et al., 1995; Bierman and Steig, 1996; Granger et al., 1996). Studies such as Riebe et al. (2000) have quantified order-of magnitude variability in erosion rates in a single mountain range using cosmogenic nuclides. However, this approach requires that the nuclide concentration in a surface be in equilibrium with erosion (i.e. nuclide accumulation equals removal by physical erosion and radioactive decay). Such a steady-state is reached once 4-5 attenuation lengths of material (of the order of $3 \mathrm{~m}$ in most cases) are removed under a constant weathering regime (Bierman and Steig, 1996). In reality, most surfaces weather by processes that are episodic at any particular location as slabs, blocks or grains are detached. Erosional steady-state is reached provided that the particles that are detached are much thinner than the penetration depth of cosmic radiation (95 per cent attenuation in $\sim 1.8 \mathrm{~m}$ : Lal, 1991). The magnitude and/or recurrence interval of discrete particle spalling or mass movement events of the type that dominate rapidly uplifting terrains can compromise the assumption of regular detachment of particles of uniform size. To take this into account, bedrock erosion rates can be estimated for discontinuously spalling surfaces by combining spatially independent samples (Small et al., 1997), but the number of independent samples required to produce representative measurements remains to be determined.

Estimating erosion rates from fluvial sediments (Brown et al., 1995; Bierman and Steig, 1996; Granger et al., 1996) in rapidly uplifting terrains may likewise be problematical. There is evidence that landsliding may confound the interpretation of erosion rates estimated from ${ }^{10} \mathrm{Be}$ concentrations of fluvial sediments collected from active orogenic settings (e.g. Pratt-Sitaula et al., 2002). However, because of the potential of cosmogenic nuclides to quantify landscape processes, researchers have begun using them in environments where mass movement is typical (e.g. Vance et al., 2003). In the first study to estimate catchment-wide erosion rates from the ${ }^{10} \mathrm{Be}$ concentration of fluvial sediment Brown et al. (1995) observed a strong negative relationship between grain size and ${ }^{10} \mathrm{Be}$ concentration, and argued that mass wasting had contributed a disproportionately large number of grains with relatively low ${ }^{10} \mathrm{Be}$ concentrations. However, no subsequent study has observed such a grain-size bias in ${ }^{10} \mathrm{Be}$ concentration and related it to mass wasting. Thus the importance of a ${ }^{10} \mathrm{Be}$ grain-size bias in fluvial sediments in active orogenic settings remains ambiguous.

It remains unclear how the 'detrital' erosion technique is influenced by periodic detachment of rock masses of thicknesses that are a significant proportion of the penetration depth of most cosmic rays $(<3 \mathrm{~m})$. Niemi et al. (2005) modelled the effect of deep-seated landslides ( $>2 \mathrm{~m}$ depth) on mean 'detrital' erosion rate estimates and found that accuracy decreases with an increasing contribution of deep-seated landslides to catchment-scale sediment flux. This issue may be most acute in active orogenic settings where shallow landslides $(<2 \mathrm{~m}$ depth) are commonplace (e.g. New Zealand Alps (Hovius et al., 1997), Taiwan (Dadson et al., 2003, 2004)). Consequently, the influence of shallow landslides (that rarely if ever exceed the penetration depth of most cosmic rays) on catchment-wide erosion rate calculations needs to be assessed so that the suitability of this technique in active orogenic settings can be judged. In addition, the assumption of steady-state erosion may be compromised during episodes of accelerated erosion, such as when a knickpoint propagates upstream, or in response to a major climatic change.

In the following sections we discuss and define the conditions within which steady-state erosion rates may be assumed and use simple computations to assess the consequences of violating this requirement. The implications of physical weathering by particle spalling (i.e. through 'chipping' of blocks or grains), frequent shallow bedrock or regolith landsliding, knickpoint propagation and climate change for catchment-averaged erosion rate determination are assessed in the Río Torrente, a small, rapidly uplifting catchment in the western Sierra Nevada, southern Spain.

\section{The Río Torrente, Sierra Nevada}

The Sierra Nevada, an $80 \mathrm{~km} \times 40 \mathrm{~km}$ east-west trending mountain block (Figure 1), is part of the trans-Mediterranean Betic-Rif mountain belt, and is the westernmost extension of the Alpine orogeny (Dewey et al., 1989). Uplift of the Sierra Nevada began during the late Miocene (Braga et al., 2003), culminating in the present $3479 \mathrm{~m}$ high mountain belt with a maximum relief of $2500 \mathrm{~m}$. Despite this high relief, the mountain summit areas are characterized by rounded tops and relatively low-angle slopes.

The Río Torrente is a small $\left(21 \mathrm{~km}^{2}\right)$, semi-arid catchment with $2 \mathrm{~km}$ relief in the western Sierra Nevada (Figures 1 and 2). No relict glacial or periglacial features are observed in this catchment, consistent with the view that latePleistocene glaciation of the Sierra Nevada was minor (Lhénaff, 1977; Sánchez et al., 1990; Gómez-Ortiz et al., 2001; Schulte, 2002); a Mediterranean climate was established in this region at the beginning of the Holocene (Jalut et al., 2000). The Torrente catchment is divided into two lithological sectors along a NE-SW axis by a major shear zone 


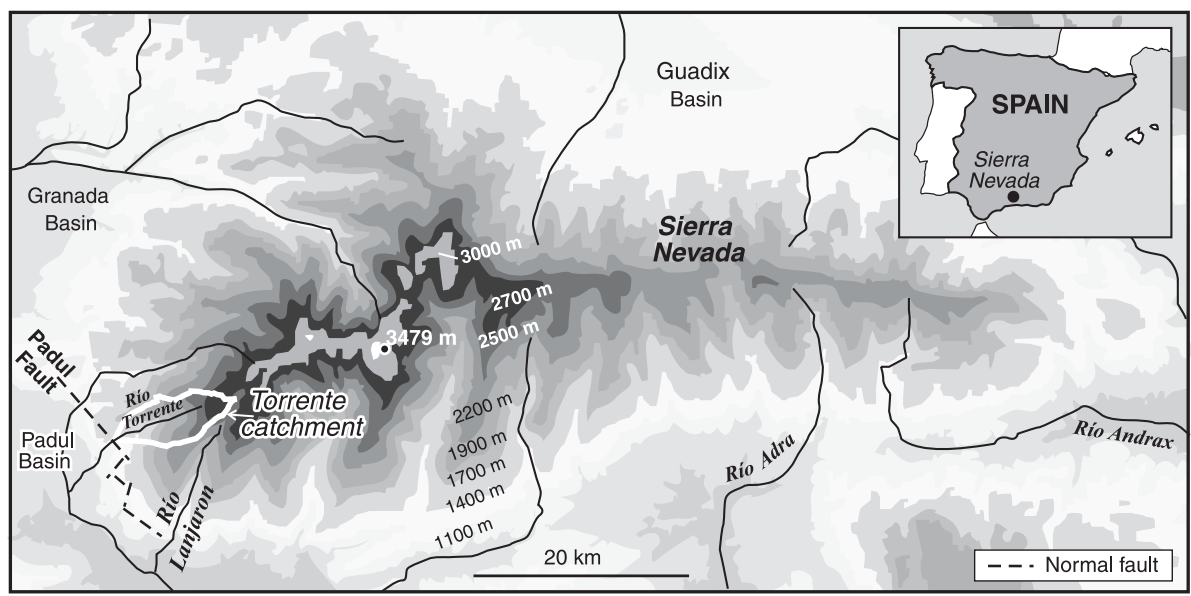

Figure I. Topographic map of the Sierra Nevada and Río Torrente catchment, generated from 30 arc-second GTOPO30 digital elevation data. Selected normal faults in the western Sierra Nevada have been highlighted, including the Padul Fault that marks the mountain front where the Río Torrente leaves the mountain block.

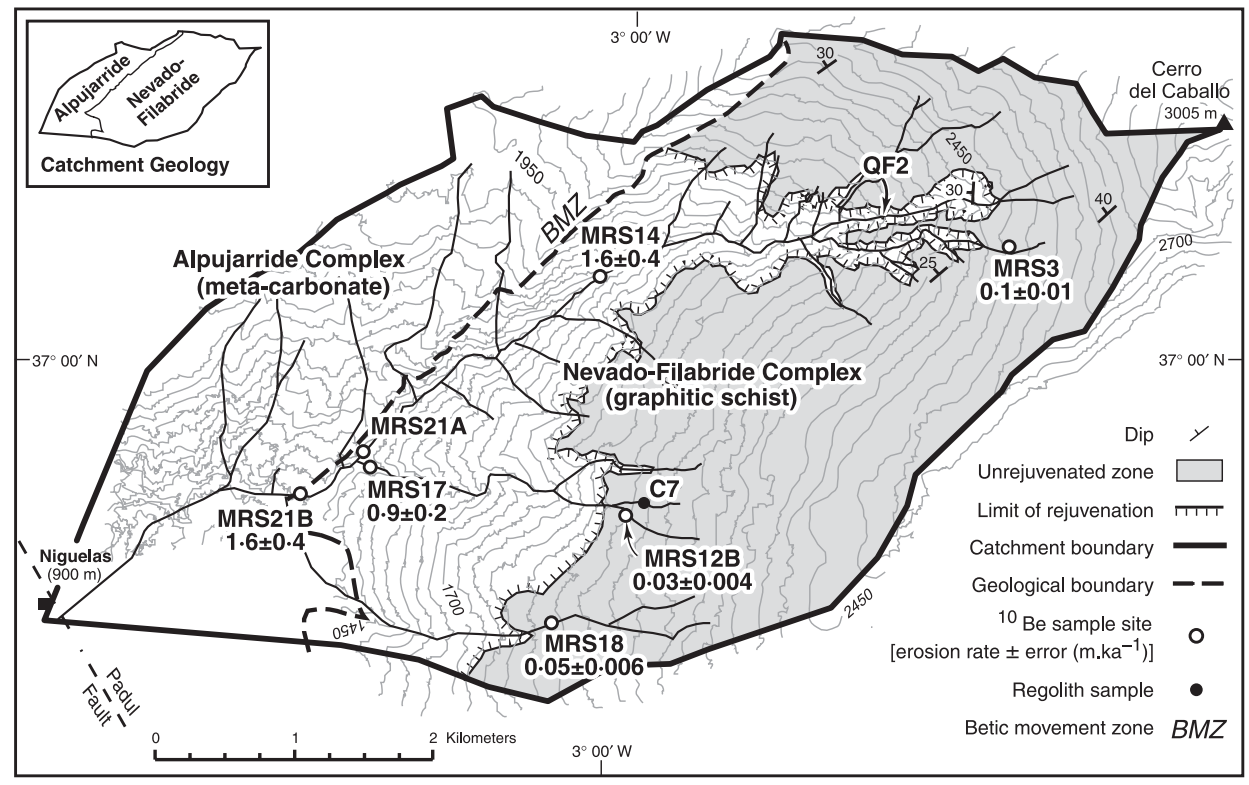

Figure 2. Combined geological and geomorphic map of the Río Torrente catchment: the topographic data were generated from a $3 \mathrm{~m} \mathrm{DEM}$. The locations of all ${ }^{10} \mathrm{Be}$ samples, the erosion rates estimated from the ${ }^{10} \mathrm{Be}$ concentration of these samples and the quartz fractionation sample site (QF2) are shown.

termed the Betic Movement Zone (BMZ) (Platt and Vissers, 1989). The schistose Nevado-Filábride unit lies SE of this axis and the Alpujárride complex to the NW. The latter is comprised of $>1 \mathrm{~km}$ thick succession of NW dipping lowgrade dolomitic marbles with occasional thin units ( $10 \mathrm{~m}$ thick) of phyllite and/or schist. Quartz is unevenly distributed in the Alpujárride part of the catchment and we did not measure ${ }^{10} \mathrm{Be}$ concentrations or investigate erosion rates within this area. The Nevado-Filábride unit comprises graphitic-mica-schist with cleavage striking parallel to the valley and is the focus of this work.

The Nevado-Filábride part of the Río Torrente catchment is comprised of two geomorphic zones. The upper, headwater parts of the catchment are characterized by relatively low slope angles $\left(<25^{\circ}\right)$, a thin regolith cover with dense low lying vegetation and low rates of fluvial incision (Sánchez-Marañón et al., 1996) (Figure 3). The lower catchment is steeper (slope angles of $25^{\circ}$ to $90^{\circ}$ ) and more sparsely vegetated (Figure 4). The Río Torrente is 


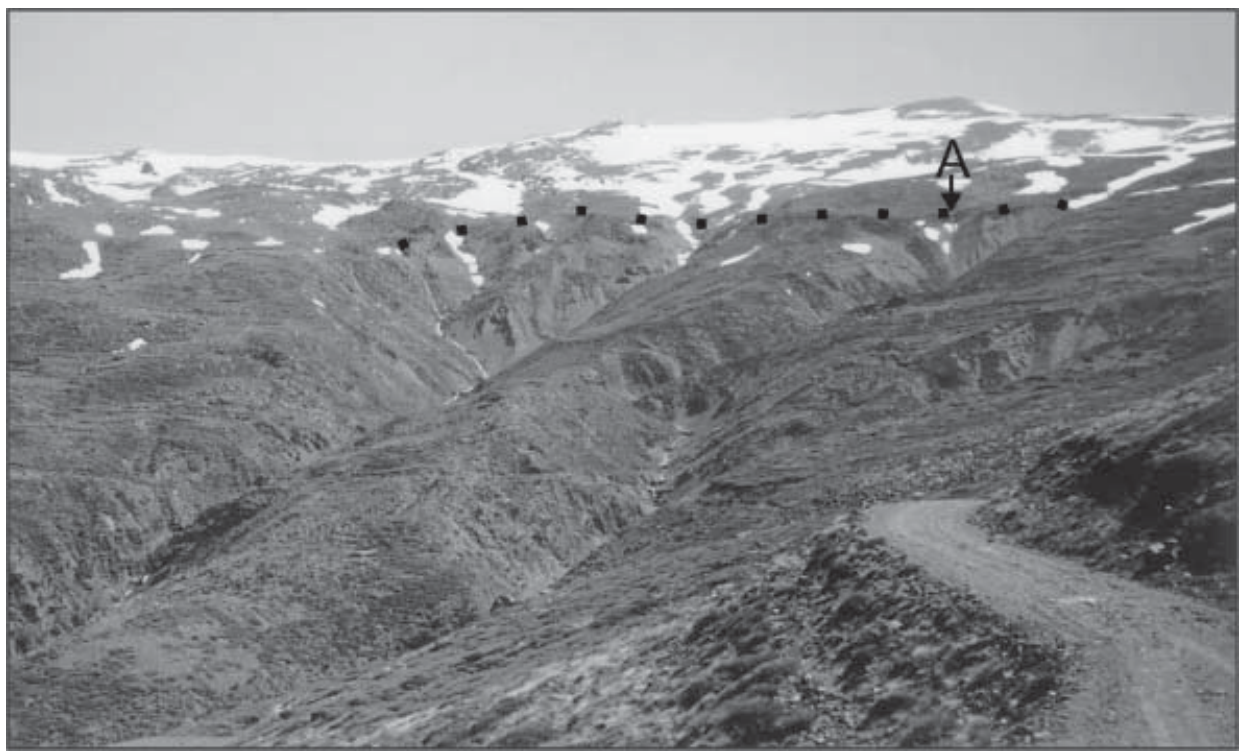

Figure 3. View of the upper Torrente catchment, looking NE towards the summit of the Cerro del Caballo ( $3005 \mathrm{~m})$. A series of major knickzones are currently propagating up the Río Torrente; the uppermost of these is shown by the dotted line (the location of knickpoint $A$ is also shown in Figure 5). The area above this knickzone is characterized by low slope angles $\left(<25^{\circ}\right)$, a thin regolith cover and low rates of fluvial incision and below, the lower catchment is steep (slope angles of $25^{\circ}$ to $90^{\circ}$ ), generally regolith-free and dominated by frequent shallow bedrock landslides.

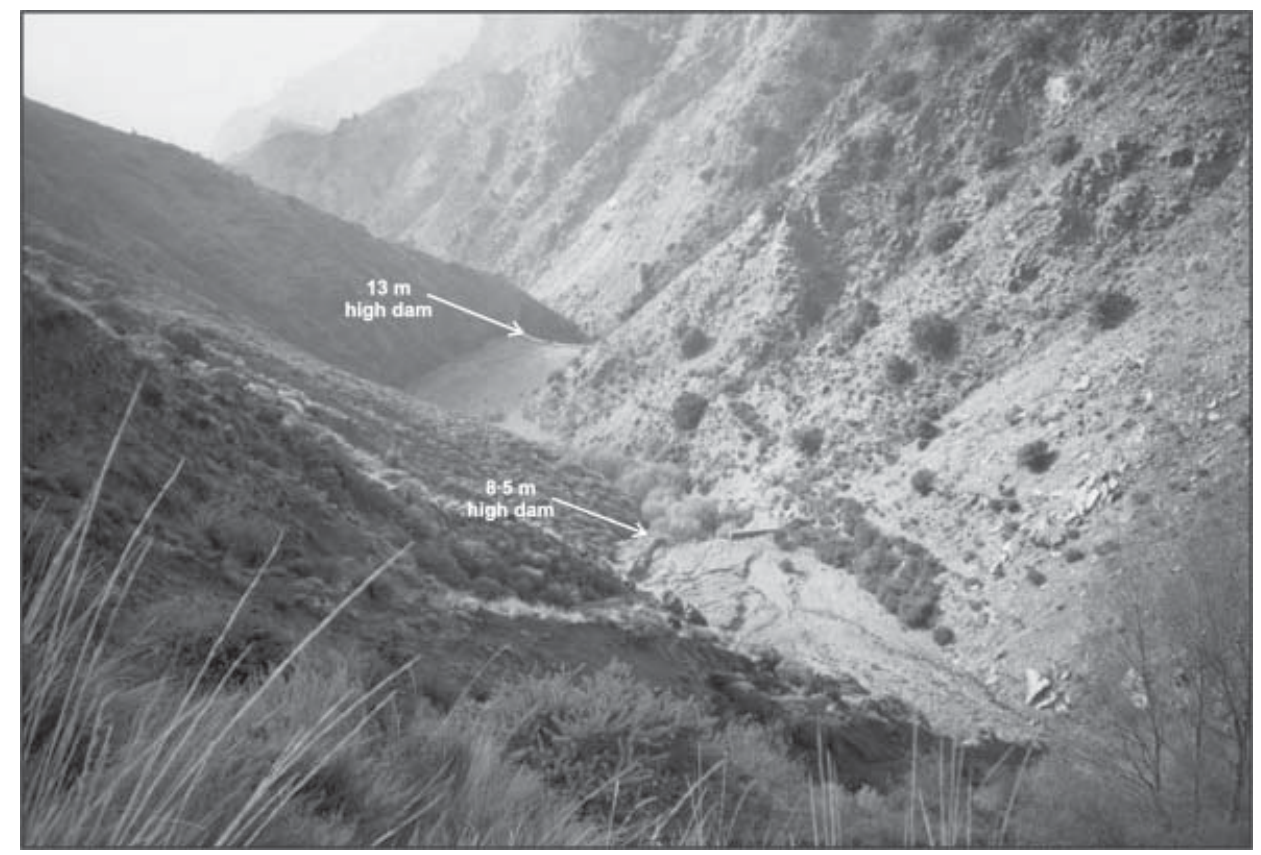

Figure 4. Downstream view of the middle, rejuvenated, reaches of the Río Torrente (c200I AD). The adjacent hillslopes are dominated by shallow bedrock landsliding. The two dams shown here were built in 198I, and in less than 20 years have completely backfilled with sediment. The approximate volume $\left(50000 \mathrm{~m}^{3}\right)$ of the two reservoirs was estimated from the dam height and surface dimensions of the sediment fill. This is good evidence that large volumes of sediment are being both produced and efficiently transported through this catchment. 


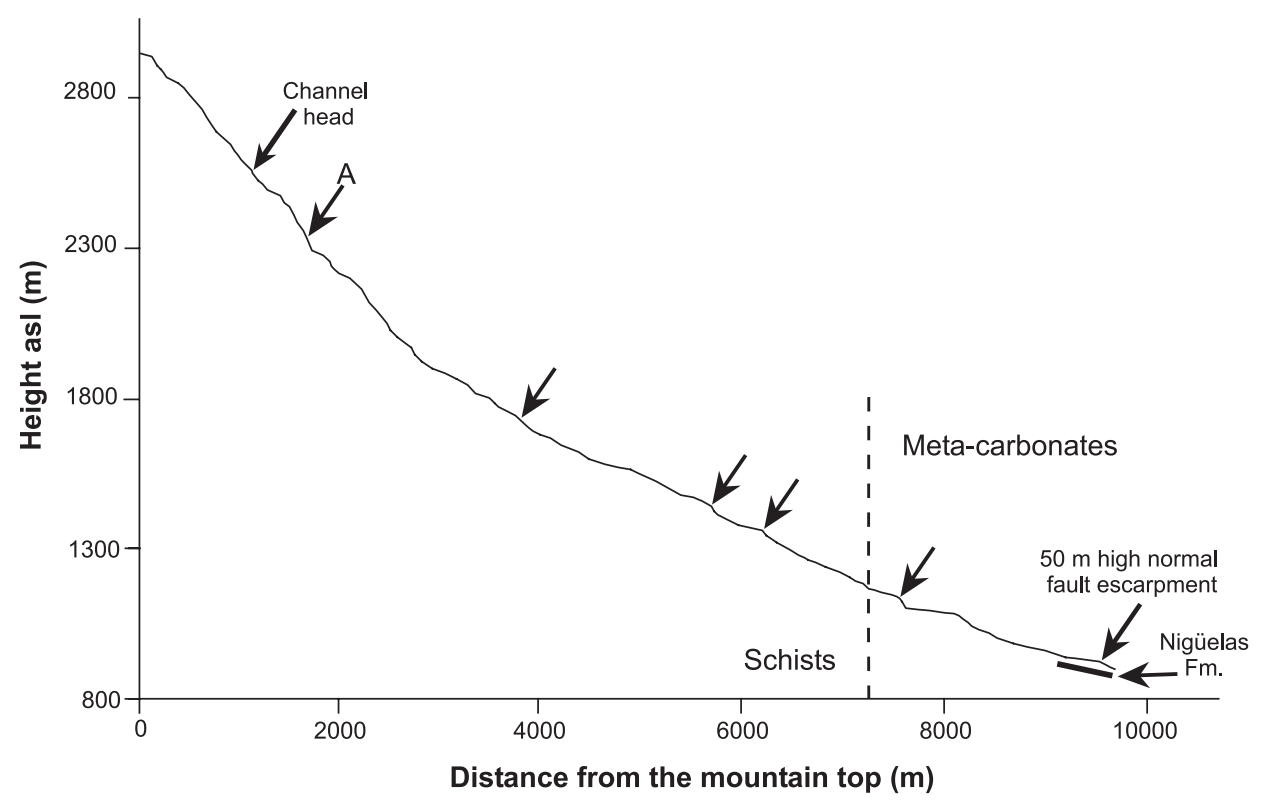

Figure 5. Long profile of the Torrente catchment following the trunk channel and a line directly from the channel head to the mountain top. Elevation data at $20 \mathrm{~m}$ contour intervals were extracted from a 1:50 000 topographic map. Some of the more prominent channel knickpoints are highlighted by arrows on the long profile (a photograph of knickpoint A is shown in figure 3). The locations of the Padul normal fault and the Nigüelas Formation are also shown.

a narrow $(<5 \mathrm{~m}$ wide) alluvial channel. The minimum rate of river incision into fluvial terrace deposits and underlying schistose bedrock, estimated from the optically stimulated luminescence dated age $(\sim 12 \mathrm{ka})$ and position of an incised fill terrace, is approximately $5 \mathrm{~m} \cdot \mathrm{ka}^{-1}$ (Reinhardt, 2005): the position of this alluvial terrace $60 \mathrm{~m}$ above the modern river bed implies that channel incision postdates terrace deposition. In the lower part of the catchment, the Río Torrente's right-bank (NW) valley wall is comprised of Alpujárride metacarbonates and the BMZ, which form a near vertical cliff that is subject to rock falls and rock slides (Figure 4) (cf. Dikau et al., 1996). On the left-bank (SE) valley wall the highly schistose Nevado-Filábride dips NW towards the axial channel at $\sim 40^{\circ}$, close to the threshold angle for landsliding. This strong schistosity promotes frequent shallow rock and debris slides, but no deep landslides with head scarps $>1 \mathrm{~m}$ in depth are observed in the schistose lower catchment (Figure 4). These shallow slides can transform into debris flows during high rainfall. The gradient of the axial Torrente (mean gradient $>0 \cdot 2$ ) lies in the range of channel slopes expected to be dominated by debris flows (slopes $>0 \cdot 05$ : Sklar and Dietrich, 1998), and debris flow deposits are observed throughout the Torrente's middle and lower reaches.

The two major geomorphic zones in the Torrente catchment are separated by the upstream-most of a series of knickzones that are propagating headwards up the Torrente from the mountain front (Figures 3 and 5). This mountain front coincides with the Padul Fault, and late Pleistocene to Holocene activity has resulted in the development of a $50 \mathrm{~m}$ high fault scarp in unconsolidated sediment of the $100 \mathrm{~m}$ thick Nigüelas formation (Fm) at the mountain front (Figure 5) (Sanz de Galdeano, 1996; Alfaro et al., 1999). It is inferred that localized tectonic movement and relative base-level fall at the mountain front is the most likely trigger for catchment rejuvenation (Reinhardt, 2005), but the detail of what has triggered the knickzones is not critical to this study.

\section{Terrestrial Cosmogenic Nuclides: A Method for Erosion Rate Calculation}

\section{Theory and limitations}

Cosmogenic nuclides such as ${ }^{10} \mathrm{Be}$ are produced in minerals by secondary cosmic-ray neutron and muon bombardment of a surface (Lal, 1991; Stone, 2000). This radiation rapidly attenuates with depth, and so spallogenic production is limited to the upper few metres of the crust, although a small amount $(<2$ per cent $)$ of muogenic production continues to depths >100 m (Heisinger, 1998; Heisinger and Nolte, 2000; Braucher et al., 2003). The concentration of 
cosmogenic nuclides in a surface is directly proportional to the length of time for which the surface has been exposed to cosmic rays, and inversely proportional to the rate of erosion (Lal, 1991). Nuclide concentrations in a surface are interpreted in terms of either a steady-state erosion rate or as an exposure age (Lal, 1991). Our study utilizes one of the best-constrained isotopic systems, ${ }^{10} \mathrm{Be}$ in quartz, to estimate erosion rates from sediment in the Río Torrente catchment (Brown et al., 1995; Bierman and Steig, 1996; Granger et al., 1996). To calculate catchment-wide erosion rates from cosmogenic nuclides in sediment, several requirements must be met.

1. The cosmogenic nuclide concentrations in the weathering surfaces must be in steady state with erosion. The effect of shallow bedrock landslides upon mean ${ }^{10} \mathrm{Be}$ concentrations in fluvial sediment remains unclear. This issue is further investigated in this study.

2. The quartz content of source area bedrock must be approximately uniform. This requirement may not be met in lithologically complex source areas, typical of active orogens.

3. Mass loss from the catchment must occur primarily through physical erosion. Chemical weathering may selectively dissolve non-quartz minerals (especially calcite), resulting in the enrichment of quartz within regolith and leading to an underestimation of erosion rates. However, selective quartz enrichment is generally negligible (Riebe et al., 2001a).

4. The isotopic flux into a catchment must equal that leaving it within fluvial sediments. This involves the following requirements.

a. Sediment storage upstream of a fluvial sediment-sampling site is negligible. For radioactive nuclides such as ${ }^{10} \mathrm{Be}$ the volume of sediment stored upstream of each sediment sample site must be either less than $c .15$ per cent of the total sediment flux over the erosional timescale $e_{\mathrm{t}}\left(e_{\mathrm{t}}=1\right.$ attenuation length $(60 \mathrm{~cm}) /$ erosion rate (Granger et al., 1996)) or else sediment storage times must be short over $e_{\mathrm{t}}$. These conditions are generally met in mountainous terrain where steep drainage networks evacuate sediment efficiently (Granger et al., 1996).

b. Erosion rates must be greater than $16 \mathrm{~m} \mathrm{Ma}^{-1}$ (for ${ }^{10} \mathrm{Be}$ ) to limit the effect of radioactive decay (Granger et al., 1996).

c. Burial of surfaces by sediment or glacial ice does not result in significant radioactive decay of the cosmogenic nuclide (Nishiizumi et al., 1989).

d. Snow or vegetation cover does not reduce cosmogenic nuclide production in the eroding surface (Kubik et al., 1998). Snow shielding in particular can depress cosmogenic nuclide production by more than 10 per cent (Schildgen et al., 2005), leading to a potential overestimation of surficial erosion rates in areas prone to snow cover. Although some attempt has been made to account for the effect of snow cover on cosmogenic nuclide production (Cerling and Craig, 1994; Licciardi et al., 1999; Schildgen et al., 2005) this problem is often explicitly (e.g. Ivy-Ochs et al., 1999) or implicitly (e.g. Small et al., 1997; Fabel et al., 2002) ignored, as the uncertainty inherent in accounting for the effects of snow shielding on cosmogenic nuclide production rate estimates over long timescales $\left(>10^{3}\right.$ a) may be much greater than any snow shielding correction factor. Moreover, systematic errors in cosmogenic nuclide production arising from snow shielding are highly localized and unlikely to exceed the systematic error associated with long-term nuclide production rate calibration (10-20 per cent: Gosse and Phillips, 2001).

5. The ${ }^{10}$ Be concentration of sampled sediment must be independent of grain-size. The importance of a cosmogenic nuclide grain-size bias in fluvial sediments in rapidly uplifting terrains remains unclear and this issue is further investigated in this study.

6. The sampled sediment must be spatially and temporally representative of all sediment leaving the catchment. The sediment must be well mixed during fluvial transport.

\section{Sample collection, preparation and measurement}

We collected and measured the ${ }^{10} \mathrm{Be}$ content of seven representative modern fluvial sediment samples from the lower (rejuvenated) and upper (unrejuvenated) parts of the Torrente catchment, plus one regolith sample from the upper catchment (Figure 2). The seven fluvial samples were collected from the Nevado-Filábride part of the catchment, where the influence of rejuvenation-related base level change is apparent and the ubiquitous presence of quartz veins suggest that quartz is evenly distributed. No large sediment deposits are observed upstream of the sampling sites because the steep drainage net efficiently evacuates sediment (Figure 4). There is no evidence of glacial activity in the Torrente catchment and snow cover is negligible.

Each fluvial sediment sample was amalgamated from the active surface layer of the channel at five to ten points within a $20-30 \mathrm{~m}$ reach. Surface grain size was determined from nine samples, each of 400 randomly sampled clasts 
$(>11 \mathrm{~mm})$, from the trunk channel. Surface layer sediments are considered representative of the full depth of mobile bed material when the sediment supply rate is very high (Lisle, 1995). The $0 \cdot 25-0.5 \mathrm{~mm}$ size fraction was collected (Granger et al., 1996; Perg et al., 2001; Schaller et al., 2001), but at five of the seven sampling sites 8-16 mm clasts were also collected to test for a grain-size bias. The river-bed sediment is very well mixed so this grain-size class, which is close to the median size of the surface sediment $\left(D_{50}=17 \mathrm{~mm}\right)$, is considered to be transported along with the $0 \cdot 25-0.5 \mathrm{~mm}$ fraction.

All samples for ${ }^{10} \mathrm{Be}$ analysis were treated with 30 per cent $\mathrm{HCl}$ and passed though a Frantz magnetic separator. The non-magnetic fraction was lightly crushed and ultrasonically etched (repeatedly, if necessary) in 2 per cent HF / 2 per cent $\mathrm{HNO}_{3}$ to isolate pure quartz, with $\mathrm{Al}<100 \mathrm{ppm}$ as measured by atomic absorption spectroscopy (Kohl and Nishiizumi, 1992). Samples were prepared using standard methods, and the ${ }^{10} \mathrm{Be} /{ }^{9} \mathrm{Be}$ ratio measured by AMS at the Department of Nuclear Physics, Australian National University, Canberra (Fifield, 1999).

To calculate ${ }^{10} \mathrm{Be}$ production rates in the catchment we generated a high-resolution $(3 \mathrm{~m})$ digital elevation model from 1:20000 aerial photographs. Production rates were calculated for the altitude of every cell following Granger et al. $(2000,2001)$ and Stone (2000), and corrected for topographic shielding (Codilean, 2006). The estimated mean surface production rate applied to each sediment sample was the mean of all cells upstream of the sampling point, and the standard deviation of these values was used as a first-order estimate of uncertainty in the mean production rate: standard production rate errors (cf. Gosse and Phillips, 2001) are fully propagated and added in quadrature.

\section{Interpreting Detrital Erosion Rate Measurement in High-relief Terrain}

Detrital ${ }^{10} \mathrm{Be}$ concentrations in the upper Torrente are consistently high (implying lower erosion rates) and are typically two orders of magnitude lower (implying higher erosion rates) in the lower altitude areas (Table I). The two-orders-ofmagnitude variation in ${ }^{10} \mathrm{Be}$ content reflects the contrasting geomorphic processes in the upper and lower catchments which are typical of emerging mountain belts (Hovius et al., 1998). In the following sections we investigate whether meaningful erosion rates may be estimated from these ${ }^{10} \mathrm{Be}$ concentrations.

\section{Geomorphic processes}

The chief difficulty in the estimation of detrital erosion rates in high-relief, tectonically active catchments is the requirement for erosional steady state. The rate of ${ }^{10} \mathrm{Be}$ accumulation in bedrock or sediment must be in equilibrium

Table I. Mean catchment erosion rates calculated from $0.25-0.5 \mathrm{~mm}$ sized sediment

\begin{tabular}{|c|c|c|c|c|}
\hline & $\begin{array}{l}\text { Altitude } \\
\text { range }(m)\end{array}$ & $\begin{array}{l}\text { Mean }{ }^{10} \mathrm{Be} \\
\text { production rate } \\
\left(\text { atoms } \mathrm{g}^{-1} \mathrm{a}^{-1}\right)\end{array}$ & $\begin{array}{c}{ }^{10} \mathrm{Be} \\
\text { concentration } \\
\left(10^{3} \text { atoms } \mathrm{g}^{-1} \mathrm{SiO}_{2}\right)\end{array}$ & $\begin{array}{c}\text { Mean catchment } \\
\text { erosion rate } \\
\left(\mathrm{m} \mathrm{ka} \mathbf{k}^{-1}\right)\end{array}$ \\
\hline \multicolumn{5}{|c|}{ Unrejuvenated upper catchment: Nevado-Filábride bedrock } \\
\hline MRS 3 & $2470-2750$ & $32 \cdot 3 \pm 2 \cdot 9$ & $211 \pm 11$ & $0.1 \pm 0.01$ \\
\hline MRS I2B & $1970-2520$ & $26 \cdot 1 \pm 3 \cdot 2$ & $650 \pm 25$ & $0.03 \pm 0.004$ \\
\hline MRS 18 & $1900-2470$ & $23 \cdot 5 \pm 2 \cdot 9$ & $397 \pm 30$ & $0.05 \pm 0.006$ \\
\hline \multicolumn{5}{|c|}{ Unrejuvenated upper catchment: regolith sample collected in areas of Nevado-Filábride bedrock } \\
\hline C7 & 1960 & $\mathrm{~N} / \mathrm{a}$ & $510 \pm 22$ & $\mathrm{~N} / \mathrm{a}$ \\
\hline \multicolumn{5}{|c|}{ Rejuvenated lower catchment: alluvial samples collected in areas of Nevado-Filábride bedrock } \\
\hline MRS 14 & $1590-3005$ & $26 \cdot 4 \pm 5 \cdot 3$ & $\mid 1 \pm 1$ & $1 \cdot 6 \pm 0.4$ \\
\hline MRS 17 & $1230-2560$ & $21.9 \pm 4.9$ & $17 \pm 1$ & $0.9 \pm 0.2$ \\
\hline MRS 2 IA & $1220-3005$ & $24 \cdot 5 \pm 6 \cdot 0$ & $14 \pm 2$ & $\mathrm{~N} / \mathrm{a}$ \\
\hline MRS 2IB & 1150-3005 & $23 \cdot 7 \pm 5 \cdot 9$ & $10 \pm 1$ & $1 \cdot 6 \pm 0.4$ \\
\hline
\end{tabular}

The ${ }^{10} \mathrm{Be}$ production rate (muon and spallation) at sea level and high latitude $\left(5 \cdot 1 \pm 0.3 \mathrm{atom}^{-1} \mathrm{a}^{-1}\right)$ is scaled to the appropriate latitude $\left(37^{\circ}\right)$ and altitude using the scaling parameters of Stone (2000), and an attenuation length of $160 \mathrm{~g} \mathrm{~cm}^{-2}$ and rock density of $2 \cdot 71 \mathrm{~g} \mathrm{~cm}^{-3}$. Mean ${ }^{10} \mathrm{Be}$ production rates are calculated from a $3 \mathrm{~m}$ digital elevation model, and corrected for topographic shielding (Codilean, 2006), using the mean of all upstream cells: standard deviation is used as a first-order estimate of production rate uncertainty. The erosion rate formulations of Granger and Smith (2000) and Granger et al. (200I, equation I) are used to calculate mean catchment erosion rates from the ${ }^{10} \mathrm{Be}$ concentration of $(0 \cdot 25-0 \cdot 5 \mathrm{~mm})$ fluvial quartz, collected from sand bars along a 20-30 m reach. Uncertainties represent one standard error measurement uncertainty; production rate and other errors (Gosse and Phillips, 200I) are fully propagated and added in quadrature. 


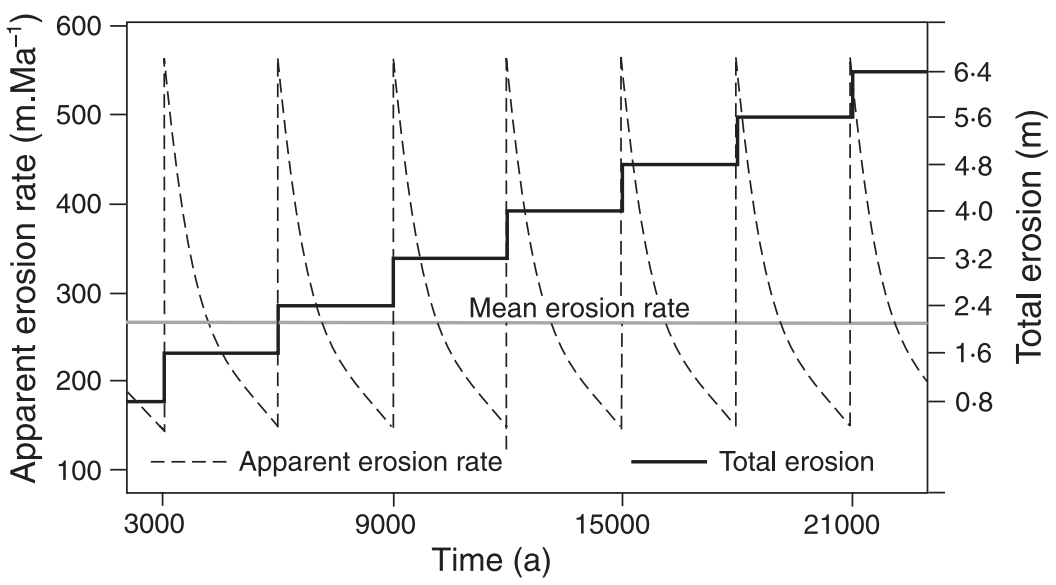

Figure 6. The results of a model simulating apparent surface erosion rates during the periodic removal of discrete particles. In this example a chip of $0.8 \mathrm{~m}$ thickness is removed every $3 \mathrm{ka}$, and no grain-by-grain attrition occurs between chipping events. This latter assumption is probably unrealistic but as we are primarily concerned with chipping events that are the same order of magnitude as the length scale of ${ }^{10} \mathrm{Be}$ production rate attenuation $($ c. $0.6 \mathrm{~m})$ it is reasonable to discount the effect of grain-by-grain attrition between chipping events. Apparent erosion rates are on the left axis and cumulative erosion on the right axis (after Small et al., 1997).

with the rate of erosion over the timescale of nuclide accumulation. In this section we: (1) calculate the conditions within which steady-state erosion rates may be estimated; and (2) assess the consequences of violating the steady-state assumption. In the next section we illustrate the results of our numerical analysis in the Torrente catchment.

Steady-state erosion Physical erosion occurs by the detachment (i.e. spalling) of particles ranging in size from small grains to large blocks and landslides. Consequently, the ${ }^{10} \mathrm{Be}$ concentration of a surface experiencing regular detachment of a grain or slab of fixed thickness and time interval varies between being greater than and less than the actual mean value, which is the value required for erosion rate estimation. Small et al. (1997) developed a onedimensional finite-difference numerical model to quantify the expected variability in bedrock erosion rates expected through this surface spalling and found that: (a) for repeated spalling cycles the variability in measured erosion rates is a function of spalling thickness and is independent of erosion rate for all rates $>10 \mathrm{~m} \mathrm{Ma}^{-1}$ (Figure 6: Small et al., 1997); and (b) erosion rate estimates are equally distributed about the mean erosion rate (Figure 6), implying that the mean value of many independent erosion rate estimates is needed to provide an accurate estimate of the true mean value. Thus if a sufficient number of bedrock samples are collected from rock surfaces at different stages of the weathering cycle, the full range of nuclide concentrations is sampled, and the actual erosion rate may be estimated by amalgamating these bedrock samples. However, the number of independent samples required to produce representative measurements has not been investigated prior to this study.

Following Small et al. (1997) we use finite-difference approximations to quantify the variability in steady erosion rates due to particle spalling at a point in the landscape, enabling the choice of an appropriate number $(n)$ of independent bedrock samples for in-situ bedrock erosion rate measurement (see Appendix). As outlined in the Appendix, the variance in apparent erosion rates over one erosion cycle may be estimated, allowing calculation of the standard error of mean erosion rates for different numbers of independent samples. As expected, the standard error of erosion rates, calculated from amalgamated independent bedrock samples, increases with spalling thickness as thicker rock fragments require larger numbers of samples to meet given uncertainty limits (Figure 7). In rapidly denuding terrain where shallow landslides rarely exceed a spalling thickness of $1 \mathrm{~m}$, amalgamating ten bedrock samples is sufficient to limit the standard error of a steady erosion rate estimate to $<10$ per cent (Figure 7). For bedrock outcrops where spalling thicknesses range from 1 to $3 \mathrm{~m}$, a large number of samples ( $>50$, depending on spalling thickness) must be amalgamated to limit standard error to $<10$ per cent (Figure 7). In our model, indistinguishable apparent erosion rates are calculated from surficial ${ }^{10} \mathrm{Be}$ concentrations for all spalling thicknesses $>3 \mathrm{~m}$. This $3 \mathrm{~m}$ upper limit is intuitively reasonable as the rate of ${ }^{10} \mathrm{Be}$ spallation production below $3 \mathrm{~m}$ is $<1$ per cent of the surface production rate and, in the type of rapidly denuding terrain that this work focuses on, ${ }^{10} \mathrm{Be}$ concentrations below this depth are negligible. Thus where spalling thickness exceeds $3 \mathrm{~m}$ depth, only minimum erosion rates may be estimated. Conversely, for spalling thicknesses $<0.1 \mathrm{~m}$, a single bedrock sample will provide an erosion rate within $<5$ per cent of the 'real' 

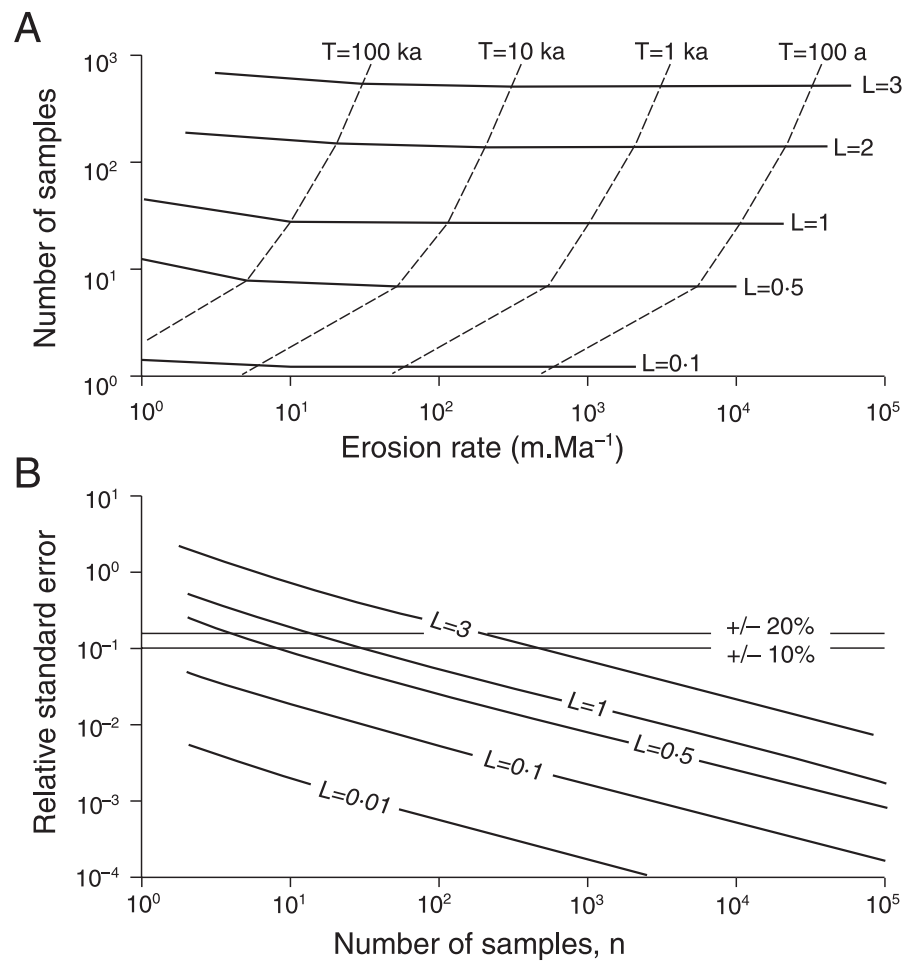

Figure 7. (A) Number of samples required to yield a relative standard error of $0 \cdot 2$ (20 per cent of the mean) as a function of erosion rate and $L$. (spalling thickness) $T$ is the reoccurrence interval of grain or chip detachment from a regularly spalling surface. The number of samples that must be amalgamated for a given spalling thickness is constant for all erosion rates $>50 \mathrm{~m} \mathrm{Ma}{ }^{-1}$, i.e. the variability in measured erosion rates is a function of spalling thickness (cf. Small et al., 1997). (B) Relative standard error (normalized by the mean erosion rate, $\varepsilon$ ) as a function of the number of samples for spalling thicknesses, $L$, of $0.0 \mathrm{I}$ to $3 \mathrm{~m}$ and erosion rates $>50 \mathrm{~m} \mathrm{Ma}^{-1}$.

erosion rate (Figure 7), far less than the 10-20 per cent uncertainty associated with production rate estimates (Gosse and Phillips, 2001).

Our model may also be applied to entire catchments where erosion is accomplished through a range of physical weathering processes ranging from grain-by-grain attrition to shallow bedrock and regolith landsliding. Once landslide material has detached from a surface and fragmented into discrete particles during transport, less than 1000 grains derived from the spalled material are needed to characterize any regular erosional event up to a depth of $3 \mathrm{~m}(c .10$ per cent relative standard error; see Equation 7 in Appendix). At the catchment scale, many such erosional events contribute towards the total sediment flux. The estimation of mean catchment erosion rates requires that these (physical) erosion events are represented in proportion to their magnitude in a fluvial sediment sample. A typical ${ }^{10} \mathrm{Be}$ sediment sample, weighing between 30 and $100 \mathrm{~g}$, contains $c .1-4 \times 10^{6}$ grains. Provided that these grains are homogenized through mixing processes and not stored for long periods, this sample size should be large enough to represent all upstream erosional events. In other words, provided that enough grains are sampled, mean erosion rates may be estimated in any landscape experiencing regular (shallow) landsliding over a range of depths not exceeding $3 \mathrm{~m}$, or $<60 \mathrm{~cm}$ in width: mean landslide thickness $(t)$ scales linearly with width $(w)(t \approx 0.05 w)$ (Ohmori, 1992; Hovius et al., 1997). In situations where landslides $>3 \mathrm{~m}$ depth occur, their effect on the accuracy of long-term erosion rate estimates depends on landslide frequency; large catchments may adequately integrate the effects of rare deep-seated landslides (Niemi et al., 2005), but in smaller catchments and/or where deep-seated landslides are common only minimum erosion rates may be calculated.

Non-steady erosion: knickpoint propagation and climate change The requirement of erosional steady state is often not satisfied in high, rapidly eroding mountain belts (Bull, 1991; Whipple, 2001). We now investigate two potential causes of disequilibrium between surface erosion and nuclide concentrations: climate change and catchment rejuvenation. Rejuvenation due to relative base level fall at the mountain front may introduce a transitory disequilibrium between the nuclide concentration at the surface and the actual erosion rate as the erosion rate changes and either 


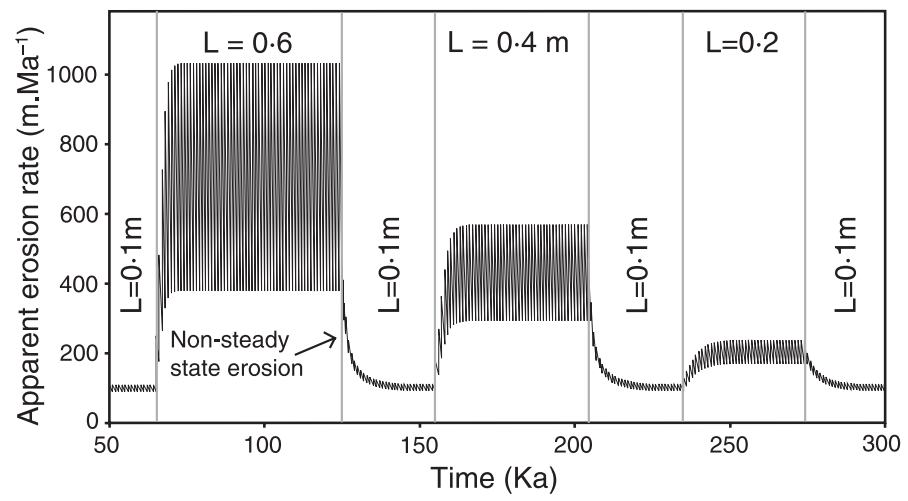

Figure 8. Graphical representation of series of dynamic changes in ${ }^{10} \mathrm{Be}$-derived erosion rates associated with permanent changes in mean erosion rate at a point in the landscape. After establishing equilibrium, erosion rates are increased six-fold at 65 ka by doubling the chip thickness $(L)$, and then the model is run until equilibrium is re-established. The mean erosion rate is then returned to the initial value $(L=0.1 \mathrm{~m})$ at $125 \mathrm{ka}$ and equilibrium is re-established. The cycle of increasing erosion rate, reestablishment of equilibrium followed by a return to the original erosion rate $(L=0.1 \mathrm{~m})$ is repeated twice for chip thicknesses of $0.4 \mathrm{~m}$ and $0.2 \mathrm{~m}$ : chipping frequency ( $\mathrm{l} \mathrm{ka}$ ) is held constant throughout the $300 \mathrm{ka}$ model run. The vertical oscillation in apparent erosion rate is due to the periodic removal of discrete particles as shown in Figure 6 . Steady state is re-established when the minimum and maximum apparent erosion rates in these oscillating ${ }^{10} \mathrm{Be}$-concentration-dependent curves attain 99 per cent of their final value for a given chip thickness. The magnitude of the oscillation in apparent erosion rate varies as a function of chip thickness $(L)$ and is independent of the erosion rate.

remains at the new value or, as in the case of upstream knickpoint migration, decreases after the perturbation has passed. These effects were simulated for a point experiencing regular detachment of a grain or chip of thickness $L$ every $T$ years. Our one-dimensional model was first run to steady state at a constant erosion rate $(L=0 \cdot 1 \mathrm{~m}: T=1000 \mathrm{a})$ and then a series of changes in mean erosion rate were introduced by changing chip thickness to $0 \cdot 6 \mathrm{~m}, 0.4 \mathrm{~m}$ and $0 \cdot 2 \mathrm{~m}$ respectively (Figure 8 ). After each change in chip thickness the model was run until steady-state conditions were re-established and the mean erosion rate was then returned to its original steady-state value $(L=0 \cdot 1 \mathrm{~m})$ in order to investigate relaxation times. Steady-state erosion was considered to have been re-established once the modelled erosion rate reached 99 per cent of its final value (Figure 8), and steady-state erosion was always re-established after a maximum of five attenuation lengths or $c .3 \mathrm{~m}$ of material were removed. Thus in the case of a discrete knickpoint, disequilibrium is short-lived and confined to a narrow zone immediately downstream of the lip of the knickpoint (see Figure 9).

Our numerical analysis also allows consideration of the effect of climate change on the interpretation of erosion rates. For example, erosion rates may decline during the transition to a relatively warm Holocene climate as periglacial and glacial activity become more restricted, resulting in disequilibrium between the new erosion rates and surficial nuclide concentrations. Our numerical analysis indicates that following a phase of accelerated cold-phase erosion, $3 \mathrm{~m}$ depth of material must be removed before ${ }^{10} \mathrm{Be}$ concentrations attain equilibrium with the new erosion rate. However, the average nuclide concentration at the surface is exponentially weighted towards the present, and nuclide accumulation is most sensitive over the time required to erode the uppermost $60 \mathrm{~cm}$ (one attenuation length). Thus, modelling of step changes in steady-state erosion shows that the effect of climatic perturbations on ${ }^{10}$ Be-based erosion rates estimates diminishes with time (Riebe et al., 2001c; see Equations 5 and 6 in the appendix of this reference). Thus, the uncertainty in erosion rate estimates arising from the transition at $c .12 \mathrm{ka}$ to a less erosive post-glacial climate is generally small (<30 per cent). However, the magnitude of this uncertainty depends upon the post-glacial erosion rate and must therefore be assessed on a case-by-case basis.

\section{Quartz production and the influence of bedrock geology}

The method for estimating catchment-wide erosion rates used here measures the average erosion rate of all quartz-contributing areas (Bierman and Steig, 1996), and assumes that the quartz content of source area bedrock is approximately uniform across the source area. The quartz content of each Torrente catchment sediment sample $(0 \cdot 25-$ $0.5 \mathrm{~mm}$ fraction; $2-5 \mathrm{~kg}$ per sample) was estimated using a Frantz magnetic separator to split each sample into quartz and non-quartz fractions and the quartz percentage by weight was calculated from the difference in sample weight 


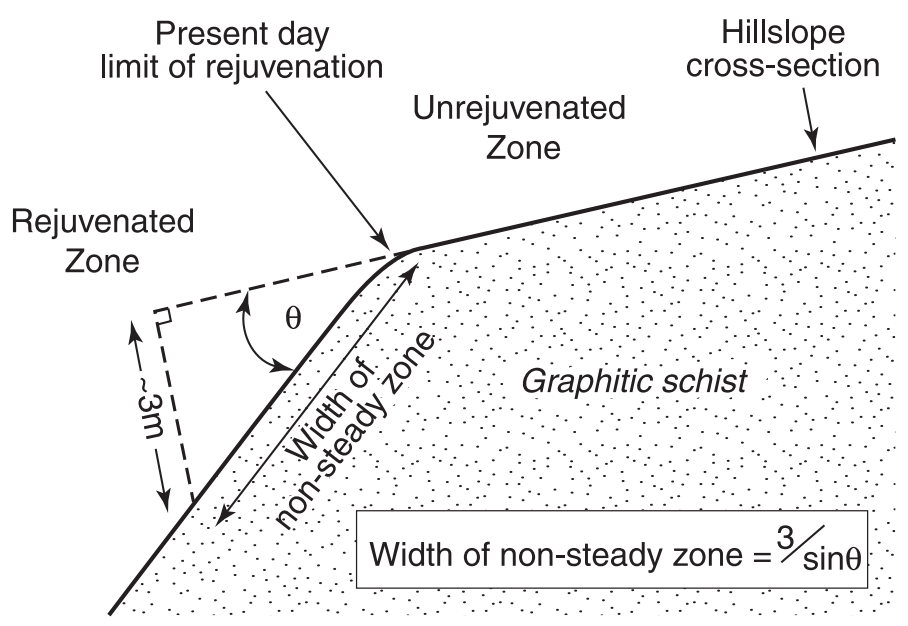

Figure 9. Schematic hillslope cross-section relating hillslope adjustment to rejuvenation with the removal of $3 \mathrm{~m}$ of material and width of the non-steady erosion zone.

Table II. Quartz content of alluvium collected in the Torrente catchment

\begin{tabular}{lc}
\hline Sample & Quartz (\%) \\
\hline MRS 3 & 15 \\
MRS I2B & 11 \\
MRS 17 & 9 \\
MRS 14 & 11 \\
\hline
\end{tabular}

before and after quartz extraction. During magnetic separation many 'impure' quartz grains were directed into the non-quartz fraction resulting in an underestimation of the quartz content of each sample. However, this systematic error applies equally to all sediment samples derived from the same lithology (schist) and a direct comparison between the quartz content of each magnetically separated sediment sample is therefore reasonable. The estimated quartz contents of the sediment samples are surprisingly uniform (12 \pm 3 per cent: Table II) supporting the assumption of uniformly distributed quartz.

Quartz is highly resistant to chemical dissolution in non-tropical environments and the presence of relatively soluble lithologies will result in quartz enrichment within regolith, increasing its residence time in the regolith and its exposure to cosmic radiation (Riebe et al., 2001a). This may lead to a significant underestimation of erosion rates calculated from ${ }^{10} \mathrm{Be}$ concentrations in fluvial quartz (Riebe et al., 2001a, b, c). Although the Nevado-Filábride schists are resistant to chemical weathering, this assumption was tested in one location in the catchment (labelled QF2 in Figure 2). Five bedrock $\left(\mathrm{QF} 2 \mathrm{~b}_{1-5}\right)$ and five overlying regolith $\left(\mathrm{QF} 2 \mathrm{r}_{1-5}\right)$ samples were collected and crushed to $<0 \cdot 25 \mathrm{~mm}$. Each sample was then immersed in 10 per cent $\mathrm{H}_{2} \mathrm{O}_{2}$ for 24 hours to remove most of the organic material, and was then dried and weighed. All non-quartz elements were dissolved in quartz-saturated $\mathrm{H}_{2} \mathrm{SiF}_{6}$ (fluorosilicic acid) and the residue dried and reweighed. The quartz content of bedrock $(42.4 \pm 2.5$ weight per cent $[1 \sigma])$ was found to be indistinguishable from regolith $(40 \cdot 7 \pm 5 \cdot 2$ weight per cent), reinforcing the view that there is no preferential chemical dissolution. Thus mass loss from the Nevado-Filábride portion of the catchment occurs predominantly through physical weathering and sediment transport.

\section{Grain size bias of ${ }^{10} \mathrm{Be}$ concentrations in fluvial quartz}

To ensure that the ${ }^{10} \mathrm{Be}$ concentration of sediment sampled is independent of grain size we measured the ${ }^{10} \mathrm{Be}$ concentration of both $0 \cdot 25-0.5 \mathrm{~mm}$ and $8-16 \mathrm{~mm}$ sized alluvium at two unrejuvenated areas in the upper catchment (MRS 3 and 12B) and three rejuvenated areas in the lower catchment (MRS 17, 21A, 21B) (Figure 2). The $(8-16 \mathrm{~mm}) /(0 \cdot 25-$ $0.5 \mathrm{~mm}){ }^{10} \mathrm{Be}$ grain-size ratio of all five samples varies by a minimum factor of two in both landslide-dominated and non-landslide-dominated terrain (Figure 10, Table III). The variation in ${ }^{10} \mathrm{Be}$ concentration with grain size is 


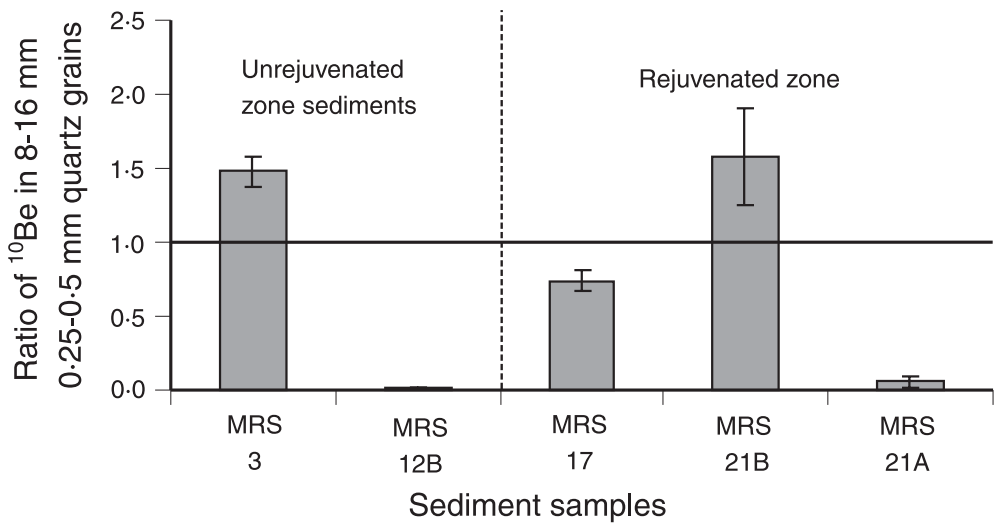

Figure 10. Ratio of ${ }^{10} \mathrm{Be}$ measured in quartz grains of $8-16 \mathrm{~mm}$ and $0.25-0.5 \mathrm{~mm}$ size fractions: $1 \sigma$ error bars. Ratios above or below the horizontal line indicate a grain-size-related variation in ${ }^{10} \mathrm{Be}$ concentration.

Table III. ${ }^{10} \mathrm{Be}$ concentrations in quartz (atoms per gram quartz) as a function of grain size ( $\sigma$ error)

\begin{tabular}{|c|c|c|c|}
\hline & \multicolumn{3}{|c|}{ Sample/grain size } \\
\hline & $0.25-0.5 \mathrm{~mm}$ & $8-16 \mathrm{~mm}$ & Grain size ratio \\
\hline \multicolumn{4}{|c|}{ Unrejuvenated zone sediments } \\
\hline MRS 3 & $210800 \pm 10500$ & $312000 \pm 14000$ & $1 \cdot 48 \pm 0 \cdot 10$ \\
\hline MRS I2B & $650000 \pm 25050$ & $5200 \pm 600$ & $0.02 \pm 0.00$ \\
\hline \multicolumn{4}{|c|}{ Rejuvenated zone sediments } \\
\hline MRS 17 & $17000 \pm 1000$ & $12200 \pm 900$ & $0.74 \pm 0.07$ \\
\hline MRS 2IB & $10500 \pm 1200$ & $17000 \pm 3000$ & $1 \cdot 58 \pm 0.33$ \\
\hline MRS 2IA & $14000 \pm 2200$ & $900 \pm 500$ & $0.06 \pm 0.04$ \\
\hline
\end{tabular}

particularly noteworthy in sample pairs MRS 21A and MRS 12B, which have ${ }^{10} \mathrm{Be}$ grain-size ratios of $0.06 \pm 0.04$ and $0.02 \pm 0.00$, respectively. MRS 12B was collected from a shallow ephemeral river channel $10 \mathrm{~m}$ upstream of an access road in the upper catchment where landsliding is not observed, and thus a landslide-generated bias is unlikely. The low ${ }^{10} \mathrm{Be}$ grain size ratio of this sample is due to the relatively low concentration of ${ }^{10} \mathrm{Be}$ in the $8-16 \mathrm{~mm}$ clasts and although no anthropogenic disturbance was observed during sample collection it is possible that these low ${ }^{10} \mathrm{Be}{ }^{8}$ $16 \mathrm{~mm}$ clasts were delivered to the site during road building. Fortunately, we have independent evidence suggesting that the ${ }^{10} \mathrm{Be}$ concentration of the $0 \cdot 25-0 \cdot 5 \mathrm{~mm}$ sediment collected at MRS $12 \mathrm{~B}$ may be used to estimate a mean upstream erosion rate. The ${ }^{10} \mathrm{Be}$ concentration in this sand-sized sediment (MRS 12B: $650 \pm 250 \times 10^{3} \mathrm{~atm} \mathrm{~g}^{-1}$ ) is similar to the ${ }^{10} \mathrm{Be}$ concentration of regolith collected from the adjacent hillslope $\left(\mathrm{C} 7: 510 \pm 22 \times 10^{3} \mathrm{~atm} \mathrm{~g}^{-1}\right)$. We thus assume that this sediment is representative of the mean sediment flux, and erosion rates have been calculated from this upper catchment sample. Conversely, no erosion rate may be estimated from the ${ }^{10} \mathrm{Be}$ concentrations of sample pair MRS 21A. This lower catchment sample pair has a very low ${ }^{10} \mathrm{Be}$ grain size ratio of $0.06 \pm 0.04$ which is consistent with landsliding, and rock- and debris-slide-generated sediments are observed in this reach. Unfortunately, the existence of a landslide-generated bias in ${ }^{10} \mathrm{Be}$ concentration in fluvial sediment is not supported by the other two samples collected in this reach (MRS 17 and MRS 21B). The ${ }^{10} \mathrm{Be}$ grain-size ratios of these latter two sample pairs are much closer to one $(0.74 \pm 0.07: 1.58 \pm 0.33)$. It is possible that these latter two samples were not influenced by recent landslide activity and that a recent landslide did perturb sample site MRS $21 \mathrm{~A}$, but the data do not support any firm conclusion as to cause of the observed bias in ${ }^{10} \mathrm{Be}$ concentration with grain size.

This is the first study to identify a grain-size bias in ${ }^{10} \mathrm{Be}$ concentration in sediments from rapidly denuding terrain. Previous studies have either: (a) ignored the effect of variation of ${ }^{10} \mathrm{Be}$ concentration with grain size on erosion rate estimates (e.g. Vance et al., 2003); (b) focused on grain sizes <2 mm (e.g. Granger et al., 1996; Schaller et al., 2001); or (c) been confined to slowly eroding river basins $\left(0.043 \mathrm{~m} \mathrm{ka}^{-1}\right.$; Brown et al., 1995). Our data support the view of 
Brown et al. (1995) that grain-size variation in ${ }^{10} \mathrm{Be}$ concentration must be considered when undertaking erosion rate estimation from ${ }^{10} \mathrm{Be}$ concentrations in fluvial sediment.

\section{Steady and Non-steady-state Erosion in the Torrente Catchment}

In the previous section we used both empirical and theoretical analysis to assess the general requirements for ${ }^{10} \mathrm{Be}$ erosion rate estimation in an active orogenic setting. We now discuss our theoretical analysis, and other site-specific considerations, in light of ${ }^{10} \mathrm{Be}$ measurements in the Torrente catchment.

\section{Upper catchment}

We collected and measured the ${ }^{10} \mathrm{Be}$ concentration of three detrital samples in the upper part of the catchment (MRS 3, MRS 12B and MRS 18). The dominant form of erosion in this portion of the catchment is downslope transport via slow diffusion of regolith that has been produced beneath a thin soil cover. ${ }^{10}$ Be-based erosion rate estimates are unaffected by this type of regolith cover (Granger et al., 1996). The three ${ }^{10} \mathrm{Be}$ samples yield estimates of $0 \cdot 1 \pm 0 \cdot 01$, $0.03 \pm 0.004$ and $0.05 \pm 0.006 \mathrm{~m} \mathrm{ka}^{-1}$, respectively, for the mean upstream erosion rate (Table I). Prior to the establishment of the current climatic regime at $c .12 \mathrm{ka}$ (Jalut et al., 2000), the Torrente catchment was subject to periglacial activity (Sánchez et al., 1990). Our numerical analysis implies that, following a phase of accelerated Late Pleistocene periglacial erosion, the slowly eroding upper catchment would have required $c$. $10^{5}$ years of erosion before $c$. $3 \mathrm{~m}$ depth was removed and nuclide concentrations were once again in steady state. As previously discussed, however, nuclide accumulation is most sensitive over the time required to erode the uppermost $60 \mathrm{~cm}$ and the formulation of Riebe et al. (2001c; Equations 5 and 6) predicts that an abrupt decrease at $12 \mathrm{ka}$ in steady erosion rates, from $0.05 \mathrm{~m} \mathrm{ka}^{-1}$ to $0.01 \mathrm{~m} \mathrm{ka}^{-1}$, would generate the estimated present-day erosion rate $\left(c .0 \cdot 03 \mathrm{~m} \mathrm{ka}^{-1}\right)$. Thus whilst the time required for ${ }^{10} \mathrm{Be}$ concentrations to equilibrate to a new erosion rate is long $\left(10^{5} \mathrm{a}\right)$, an order-of-magnitude modern erosion rate may be estimated from fluvial sediments in slowly eroding post-periglacial environments such as the upper Torrente catchment, provided that physical erosion has been in steady state during the Holocene.

\section{Lower catchment}

The lower Torrente catchment, being dominated by shallow $(<1 \mathrm{~m})$ rock and debris slides (Figure 4$)$, is an ideal location for assessing whether ${ }^{10} \mathrm{Be}$ data can provide meaningful erosion rates in rapidly eroding settings. ${ }^{10} \mathrm{Be}$ measurements are not substantially affected by recent debris flow activity, as the time required for a typical sediment grain to be exhumed from a hillslope and transported to a small channel or hollow is much longer than the time required for it to be transported through the fluvial channel network (Kirchner et al., 2001). However, the upstream boundary of the lower catchment is a narrow, headward-propagating knickzone where erosion has not reached steady state, adding complexity to this interpretation (Figure 5). Fortunately, this 15-20 m wide knickzone occupies less than 2 per cent of the contributing area of sediment sampled in this study. Consequently, although erosion rates are locally high, the zone of non-steady-state erosion contributes a relatively low proportion of the downstream sediment flux. Therefore the cosmogenic nuclide concentration in sediments downstream of knickpoints, once homogenized through fluvial mixing, should provide meaningful erosion rate estimates.

Our theoretical analysis, implying that detrital erosion rates are unaffected by frequent shallow $(<3 \mathrm{~m})$ regolith or bedrock landslides, is supported by the post-rejuvenation river incision rate and internally consistent erosion rate measurements in the lower catchment. Mean catchment-wide erosion rates were calculated from three sediment samples with overlapping source areas in the lower catchment: erosion rates were not estimated from the fourth sample (MRS 21A) as the ${ }^{10} \mathrm{Be}$ concentration of this sample is sensitive to grain size. The rates are $1.6 \pm 0.4 \mathrm{~m} \mathrm{ka}{ }^{-1}$ for MRS $14,0.9 \pm 0.2 \mathrm{~m} \mathrm{ka}^{-1}$ for MRS 17 and $1.6 \pm 0.4 \mathrm{~m} \mathrm{ka}^{-1}$ for MRS 21B. These three erosion rates are quite similar and yield a mean catchment-wide erosion rate of $1.4 \pm 0.6 \mathrm{~m} \mathrm{ka}^{-1}$. This rate means that the surface is lowered by $3 \mathrm{~m}$ in c. 2000 years. This period is probably sufficiently short for the rate of landscape lowering in this zone of high slope angles to have remained constant during this time, meaning that the zone is likely to be in erosional steady state. The mean catchment-wide erosion rate of $1.4 \mathrm{~m} \mathrm{ka}^{-1}$ is, as expected, close to but lower than the rate of axial channel incision into bedrock in the lower catchment, based on $(12 \mathrm{ka})$ fluvial terrace deposits dated by optically stimulated luminescence $\left(5 \mathrm{~m} \mathrm{ka}^{-1}\right.$ : Reinhardt, 2005). The rate of river incision exceeds mean catchment-wide erosion rate estimates because the mean erosion rate is an integration of all upstream areas including the slowly eroding upper catchment $\left(0 \cdot 03-0 \cdot 1 \mathrm{~m} \mathrm{ka}^{-1}\right)$. Therefore careful sampling enables order-of-magnitude, or better, ${ }^{10} \mathrm{Be}-$ based erosion rates to be estimated in this active orogenic setting. 


\section{Conclusions}

The two-order-of-magnitude range in ${ }^{10} \mathrm{Be}$-based erosion rate estimates in the Torrente $\left(0 \cdot 03-1.6 \mathrm{~m} \mathrm{ka}^{-1}\right)$ quantifies the high degree of spatial variation in rates of erosion expected within rapidly uplifting catchments. Numerical analysis, supported by ${ }^{10} \mathrm{Be}$-based erosion rate measurement in the Torrente catchment, confirms that the detrital erosion rate measurement technique developed by Brown et al. (1995), Bierman and Steig (1996) and Granger et al. (1996) is valid in rapidly denuding catchments, provided that erosion is accomplished through shallow $(<3 \mathrm{~m})$ physical weathering and the duration of sediment storage is negligible. Where landslides $>3 \mathrm{~m}$ deep are the dominant mode of erosion, only minimum erosion rates may be calculated. Simple computations (Equations 3 and 7) quantify the variability in steady erosion rates due to particle spalling in rapidly eroding terrains, and enable calculation of the number of bedrock samples that must be amalgamated for the estimation of mean erosion rates on an outcrop experiencing regular detachment of a grain or chip of thickness $L$ every $T$ years. We find that bedrock outcrops that spall particle thicknesses of 1-3 m require the amalgamation of material from $>50$ bedrock samples for the accurate estimation of erosion rates. Only one bedrock sample is required to assess erosion if spalling thicknesses are $<0 \cdot 1 \mathrm{~m}$. We also find that a minimum two-fold variability in ${ }^{10} \mathrm{Be}$ concentration with grain size may be expected in sediment collected from rapidly denuding terrain. Grain-size variation in ${ }^{10} \mathrm{Be}$ concentration must therefore be considered when undertaking erosion rate estimation from ${ }^{10} \mathrm{Be}$ concentrations in fluvial sediment.

\section{Acknowledgements}

We gratefully acknowledge support from the CRUST project (Scottish Higher Education Funding Council Research Development Grant), the Mac Robertson Travelling Scholarship (University of Glasgow), the Leverhulme and Carnegie Trusts, the UK Engineering and Physical Sciences Research Council and the British Geomorphological Research Group. L.R. thanks John Chappell, Derek Fabel, Abaz Alimanovic and all the staff at the Department of Nuclear physics at the ANU for their invaluable advice and encouragement during his stay, and Anne Dunlop and Mike Shand for assistance with the digital photogrammetry and cartography. Comments from D. Burbank and an anonymous reviewer greatly improved this manuscript.

\section{Appendix}

\section{Numerical analysis}

We use finite difference approximations to quantify the variability in steady erosion rates due to particle spalling, and thereby constraining the conditions within which steady-state erosion rates may be estimated. Erosion cannot automatically be assumed to be regular for two reasons: (1) the thicknesses of eroding fragments, $L$, can be the same order of magnitude as $z^{*}$ (length scale of attenuation, c. $0.6 \mathrm{~m}$ ), so erosion is episodic on the ${ }^{10} \mathrm{Be}$ timescale; (2) permanent changes in erosion rate, such as following rejuvenation, cause a period of non-steady erosion prior to establishment of an equilibrium erosion rate. To investigate the impact of these factors on the variability in apparent erosion rates, we apply finite difference approximations and introduce changes in erosion rate through time.

Near-surface spalling to $<3 \mathrm{~m}$ depth does not have a significant influence upon muogenically produced ${ }^{10} \mathrm{Be}$ concentration and is not considered in the following calculations; but muons are incorporated into the erosion rate estimates cited in the text because rapid exhumation increases their relative importance (Granger et al., 2001). We begin our theoretical calculations with a surface zero concentration of ${ }^{10} \mathrm{Be}$, and the concentration undergoes an initial phase of equilibration with the imposed erosion rate. Once equilibrium is attained, an erosional 'event' is introduced leading to exposure of rock with low ${ }^{10} \mathrm{Be}$ content (Figures 6 and 8), and consequently a high calculated erosion rate. The mean erosion rate is $L / T_{e}$, where $T_{\mathrm{e}}$ is the period (in years, a) between a grain or block failure of thickness $L$. If the mean rate is estimated from samples that are randomly distributed through the interval $T_{e}$ (i.e. samples are collected from rock surfaces at different stages in the chipping cycle, enabling samples to be collected from the full range of ${ }^{10} \mathrm{Be}$ content) then the standard error of the mean can be estimated from the variance of the calculated erosion rates. Nuclide concentration is expressed as a function of depth (Equation 1) and surface concentration (Equation 2) where $P_{0}$ is the surface production rate (atoms $\mathrm{g}^{-1} \mathrm{a}^{-1}$ ), $\lambda$ is the nuclide decay constant, $t$ is time, and $N^{\prime}$ is the concentration at the base of the eroded fragment at the moment of erosion.

$$
\begin{gathered}
N(z)=N_{0} \exp \left(-z / z^{*}\right) \\
N_{0}=\left(P_{0} / \lambda\right)(1-\exp (-\lambda t))+N^{\prime} \exp (-\lambda t)
\end{gathered}
$$


Solving Equations 1 and 2 for $N^{\prime}$ with a period $T_{e}$ between spalling events by defining the thickness of the eroded fragment $L$ such that Equation 1 becomes $N^{\prime}=N_{0} \exp \left(-L / z^{*}\right)$ yields:

$$
N^{\prime}=\frac{P_{0} e^{-L / z^{*}}\left(1-e^{-\lambda T_{e}}\right)}{\lambda\left(1-e^{-\lambda T_{e}} e^{-L / z^{*}}\right)}
$$

The instantaneous steady-state erosion rate, $\varepsilon$ is given by Equation 4 . Here the nuclide concentration at the surface given by Equation 2, $N_{0}$, is a function of time as it varies according to the thickness of eroded fragments and the time since removal of the last fragment:

$$
\varepsilon=z^{*}\left[\left(P_{0} / N_{0}\right)-\lambda\right]
$$

Equation 4 can be solved to yield the variance in calculated erosion rates over one erosion cycle, i.e. between time $t=0$ and $t=T_{e}$. This relies on the following expression for variance (Equation 5) and solution of Equation 6 for the mean and sum of squares of erosion rate:

$$
\begin{gathered}
\sigma^{2}(\varepsilon)=\overline{\varepsilon^{2}}-\bar{\varepsilon}^{2} \\
\overline{\varepsilon^{2}}=\frac{1}{T_{e}} \int_{0}^{T_{e}} \varepsilon^{2} d t \\
\bar{\varepsilon}^{2}=\left[\frac{1}{T_{e}} \int_{0}^{T_{e}} \varepsilon d t\right]^{2}
\end{gathered}
$$

Using Equations 2, 3, 4 and 6 to solve Equation 5 yields an expression for the variance of erosion rate (Equation 7):

$$
\sigma^{2}(\varepsilon)=\frac{z_{*}^{2} \lambda}{T_{e}}\left[\frac{\left(N^{\prime} \lambda-P_{0}\right)}{N^{\prime} \lambda-P_{0}\left(1-e^{\lambda T_{e}}\right)}+\lambda T_{e}-\ln \left[N^{\prime} \lambda-P_{0}\left(1-e^{\lambda T_{e}}\right)\right]-1+\frac{P_{0}}{N^{\prime} \lambda}+\ln \left(N^{\prime} \lambda\right)\right]-\frac{L^{2}}{T_{e}^{2}}
$$

The standard error of estimates of mean erosion rate for different numbers of independent samples $(n)$ is then calculated as $\sigma^{2}(\varepsilon) / n^{0.5}$ (Figure 7).

\section{References}

Alfaro P, Galinod-Zaldievar J, Jabaloy A, López-Garrido A, Sanz de Galdeano C. 1999. Evidencias de actividad y paleosismicidad de la falla de Padul (Cordillera Bética, sur de España). Acta Geologica Hispanica 36: 283-297.

Bierman PR, Steig EJ. 1996. Estimating rates of denudation using cosmogenic isotope abundances in sediment. Earth Surface Processes and Landforms 21: 125-139.

Braga J, Martin J, Quesada C. 2003. Patterns and average rates of late Neogene-Recent uplift of the Betic Cordillera, SE Spain. Geomorphology 50: $3-26$.

Braucher R, Brown ET, Bourlès D, Colin F. 2003. In situ produced ${ }^{10} \mathrm{Be}$ measurements at great depths: implications for production rates by fast muons. Earth and Planetary Science Letters 211: 251-258.

Brown ET, Stallard RF, Larsen MC, Raisbeck GM, Yiou F. 1995. Denudation rates determined from the accumulation of in situ-produced 10Be in the Luquillo Experimental Forest, Puerto Rico. Earth and Planetary Science Letters 129: 193-202.

Burbank DW. 2002. Rates of erosion and their implications for exhumation. Mineralogical Magazine 66: 25-52.

Burbank DW, Leland J, Fielding E, Anderson R, Brozovic N, Reid M, Duncan C. 1996. Bedrock incision, rock uplift and threshold hillslopes in the northwestern Himalayas. Nature 379: 505-510.

Bull WB. 1991. Geomorphic Responses to Climatic Change. Oxford University Press: London.

Calvache M, Viseras C, Fernandez J. 1997. Controls on fan development: evidence from fan morphometry and sedimentology; Sierra Nevada, SE Spain. Geomorphology 21: 69-84.

Cerling TE, Craig H. 1994. Geomorphology and in-situ cosmogenic isotopes. Annual Reviews of Earth and Planetary Sciences 22: 273317.

Codilean AT. 2006. Calculation of the cosmogenic isotope production topographic shielding scaling factor for large areas using DEMs. Earth Surface Processes and Landforms 31: $785-794$.

Dadson SJ, Hovius N, Chen WH, Dade B, Hsieh ML, Willett SD, Hu JC, Horng MJ, Chen MC, Stark CP, Lague D, Lin JC. 2003. Links between erosion, runoff variability and seismicity in the Taiwan orogen. Nature 426: 648-651. 
Dadson SJ, Hovius N, Chen WH, Dade B, Lin JC, Hsu ML, Lin CW, Horng MJ, Chen TC, Milliman J, Stark CP. 2004. Earthquake-triggered increase in sediment delivery from an active mountain belt. Geology 32: 733-736.

Dewey J, Helman M, Turco E, Hutton D, Knott S. 1989. Kinematics of the western Mediterranean. In Alpine Tectonics, Coward M, Dietrich D, Park R (eds). Special Publication 45. Geological Society: London; 265-283.

Dikau R, Brunsden D, Schrott L, Ibsen M-L. 1996. Landslide Recognition: Identification, Movement and Causes. John Wiley and Sons: Chichester.

Fabel D, Stroeven A, Harbor J, Elmore D, Fink D. 2002. Landscape Preservation under Fennoscandian ice sheets determined from in-situ produced Be-10 and Al-26. Earth and Planetary Science Letters 201: 397-406.

Fifield K. 1999. Accelerator mass spectrometry and its applications. Reports on Progress in Physics 62: 1223-1274.

Gilbert G. 1909. The convexity of hilltops. Journal of Geology 17: 344-350.

Gómez A, Palacios D, Ramos M, Tanarro L, Schulte L, Salvador F. 2001. Location of permafrost in marginal regions: Corral del Veleta, Sierra Nevada, Spain. Permafrost and Periglacial Processes 12: 93-110.

Gosse J, Phillips F. 2001. Terrestrial in situ cosmogenic nuclides: theory and application. Quaternary Science Reviews 20: $1475-1560$.

Granger DE, Smith AL. 2000. Dating buried sediments using radioactive decay and muogenic production of ${ }^{26} \mathrm{Al}$ and ${ }^{10} \mathrm{Be}$. Nuclear Instruments and Methods in Physics Research Section B: Beam Interactions with Materials and Atoms 172: 822-826.

Granger DE, Kirchner JW, Finkel RC. 1996. Spatially averaged long-term erosion rates measured from in situ produced cosmogenic nuclides in alluvial sediment. The Journal of Geology 104: 249-257.

Granger DE, Riebe CS, Kirchner JW, Finkel RC. 2001. Modulation of erosion on steep granitic slopes by boulder armouring, as revealed by cosmogenic ${ }^{26} \mathrm{Al}$ and ${ }^{10} \mathrm{Be}$. Earth and Planetary Science Letters 186: 269-281.

Heisinger B. 1998. Myonen-induzierte produktion von radionukliden. PhD Thesis, Technical University of Munich.

Heisinger B, Nolte E. 2000. Cosmogenic in situ production of radionuclides: Exposure ages and erosion rates. Nuclear Instruments and Methods in Physics Research Section B: Beam Interactions with Materials and Atoms 172: 790-795.

Hovius N, Stark CP, Allen PA. 1997. Sediment flux from a mountain belt derived by landslide mapping. Geology 25: 231-234.

Hovius N, Stark C, Tutton M, Abbott L. 1998. Landslide-driven drainage network evolution in a pre-steady-state mountain belt: Finisterre Mountains, Papua New Guinea. Geology 26: 1071-1074.

Ivy-Ochs S, Schluchter C, Kubik P, Denton G. 1999. Moraine exposure dates imply synchronous Younger Dryas glacier advances in the European Alps and the Southern Alps of New Zealand. Geografiska Annaler Series A Physical Geography 81A: 313-323.

Jalut G, Esteban A, Bonnet L, Gauquelina T, Fontugnec M. 2000. Holocene climatic changes in the Western Mediterranean, from south-east France to south-east Spain. Palaeogeography, Palaeoclimatology, Palaeoecology 160: 255-290.

Kirchner JW, Finkel R, Riebe CS, Granger D, Clayton J, King J, Megahan W. 2001. Mountain erosion over 10 yr, 10 k.y., and 10 M.y. time scales. Geology 29: 591-594.

Kohl C, Nishiizumi K. 1992. Chemical isolation of quartz for measurement of in-situ-produced cosmogenic nuclides. Geochimica et Cosmochimica Acta 56: 3583-3587.

Kubik P, Ivy-Ochs S, Masarik J, Frank M, Schluchter C. 1998. 10Be and 26Al production rates deduced from an instantaneous event within the dendro-calibration curve, the landslide of Köfels, Ötz Valley, Austria. Earth and Planetary Science Letters 161: $231-241$.

Lal D. 1991. Cosmic ray labelling of erosion surfaces: in situ nuclide production rates and erosion models. Earth and Planetary Science Letters 104: 424-439.

Lhénaff R. 1977. Recherches Geomorphologiques sur les cor Dilleres Betiques Centre accidentales. PhD thesis, University of Lille.

Licciardi JM, Kurz MD, Clark PU, Brook EJ. 1999. Calibration of cosmogenic 3He production rates from Holocene lava flows in Oregon, USA, and effects of Earth's magnetic field. Earth and Planetary Science Letters 172: 261-271.

Lisle T. 1995. Particle size variation between bedload and bed material in natural gravel bed channels. Water Resources Research 31: 11071118.

Montgomery D, Brandon M. 2002. Topographic controls on erosion rates in tectonically active mountain ranges. Earth and Planetary Science Letters 201: 481-489.

Montgomery D, Dietrich WE. 1994. A physically based model for the topographic control on shallow landsliding. Water Resources Research 30: $1153-1171$.

Niemi NA, Oskin M, Burbank DW, Heimsath AJ, Gabet EJ. 2005. Effects of bedrock landslides on cosmogenically determined erosion rates. Earth and Planetary Science Letters 237: 480-498.

Nishiizumi K, Winterer EL, Kohl CP, Klein J, Middleton R, Lal D, Arnold JR. 1989. Cosmic ray production rates of 10Be and 26Al in quartz from glacially polished rocks. Journal of Geophysical Research 94: 17907-17915.

Ohmori H. 1992. Morphological characteristics of the scar created by large-scale rapid mass movement. Japanese Geomorphological Union Transactions 13: 185-202.

Perg LA, Anderson RS. 2001. Use of a new ${ }^{10} \mathrm{Be}$ and ${ }^{26} \mathrm{Al}$ inventory method to date marine terraces, Santa Cruz, California, USA. Geology 29: 879-882.

Platt J, Vissers R. 1989. Extensional collapse of thickened continental lithosphere: a working hypothesis for the Alboran Sea and Gibralter arc. Geology 17: 540-543.

Pratt-Sitaula B, Burbank DW, Heimsath AH, Ojha T. 2002. Impulsive alluviation during early Holocene strengthened monsoons, central Nepal Himalaya. Geology 30: 911-914.

Reinhardt LJ. 2005. Tectonics and Topography: A Study of Mountain Denudation in Southern Spain. PhD Thesis, University of Glasgow.

Riebe CS, Kirchner JW, Granger DE. 2001a. Quantifying quartz enrichment and its consequences for cosmogenic measurements of erosion rates from alluvial sediment and regolith. Geomorphology 40: 15-19. 
Riebe CS, Kirchner JW, Granger DE, Finkel RC. 2001b. Strong tectonic and weak climatic control of long-term chemical weathering rates. Geology 29: 511-514.

Riebe CS, Kirchner JW, Granger DE, Finkel RC. 2001c. Minimal climatic control on erosion rates in the Sierra Nevada, California. Geology 29: 447-450.

Sánchez S, Simón M, García A. 1990. Morfogensis glaciar de la cuenca del Río Lanjaron (Sierra Nevada-Granada). In Actas 1 Reunión Nacional de Geomorfología. Sociedad Española de Geomorfologia, Gutiérrez M, Peña J, Lozano M (eds). Teruel: $203-210$.

Sánchez-Marañón M, Delgado R, Párraga J, Delgado G. 1996. Multivariate analysis in the quantitative evaluation of soils for reforestation in the Sierra Nevada (southern Spain). Geoderma 69: 233-248.

Sanz de Galdeano C. 1996. Neotectonica y nectonica activa en el sector de Padul-Durcal (borde sw de Sierra Nevada, Espana). In 1 st Conferencia Internacional Sierra Nevada, Chacon J, Rosua J (eds) 1: 219-231.

Schaller M, Blanckenburg F, Hovius N, Kubik P. 2001. Large-scale erosion rates from in situ-produced cosmogenic nuclides in European river sediments. Earth and Planetary Science Letters 188: 441-458.

Schildgen TF, Phillips WM, Purves RS. 2005. Simulation of snow shielding corrections for cosmogenic nuclide surface exposure studies. Geomorphology 64: 67-85.

Schulte L. 2002. Climatic and human influence on river systems and glacier fluctuations in southeast Spain since the last glacial maximum. Quaternary International 93-94: 85-100.

Sklar L, Dietrich WE. 1998. River longitudinal profiles and bedrock incision models: Stream power and the influence of sediment supply. In Rivers Over Rock: Fluvial Processes in Bedrock Channels, Tinkler K, Wohl E (eds). American Geophysical Union: Washington DC; 237260.

Small E, Anderson R, Repka J, Finkel B. 1997. Erosion rates of alpine bedrock summit surfaces deduced from in situ ${ }^{10} \mathrm{Be}$ and ${ }^{26} \mathrm{Al}$. Earth and Planetary Science Letters 150: 413-425.

Stone J. 2000. Air pressure and cosmogenic isotope production. Journal of Geophysical Research B 105: 23753-23759.

Vance D, Bickle D, Ivy-Ochs S, Kubik P. 2003. Erosion and exhumation in the Himalaya from cosmogenic isotope inventories of river sediments. Earth and Planetary Science Letters 206: 273-288.

Whipple KX. 2001. Fluvial landscape response time: How plausible is steady-state denudation? American Journal of Science 301: 313-325. 